\title{
THE BIRDS OF THE AUGRABIES FALLS NATIONAL PARK
}

\author{
by \\ J. M. WINTERBOTTOM*
}

The Augrabies Falls National Park lies astride the Orange River at about $28^{\circ} 30^{\prime}$ S., $20^{\circ} 20^{\prime}$ E. On the north bank of the River, the Park extends from a point about 3 miles upstream of the falls to a point just below them; on the south bank, from a point one mile upstream to the end of the Gorges, seven miles below the falls.

The bird habitats of the Park may be classified as:

1. Orange River. Tremendous fluctuations in the water-level take place and, at its lowest, it may be crossed without wetting the feet. At its highest, it is several miles broad above the falls. The water is always muddy and the bird life sparse.

2. Gorges below the falls. Steep cliffs form the walls and the river, deeper than above, forms the bottom, with, at most, a narrow belt of rocks and mud, with some riverine bush, between it and the cliffs.

3. Riverine Bush, composed chiefly of acacias and tamarisks and much the richest habitat for birds. Above, and for a little way below, the falls, the river has many side-channels, each lined with this bush.

4. Namaqua Broken Veld (Acocks, 1953) is the bush-type away from the river. Scattered trees and bushes of Acacia, Aloe and other genera occur and there is a sparse grass cover.

5. Irrigated Land. This is, strictly speaking, outside the Park, but that between the main road and the Park boundary has been included in this survey.

When the Park was first established, only the upper portion of the gorges was included; but there was an extent of Namaqua Broken Veld on the south side between the road and the river which fell within its boundaries. Subsequently, this flat land was exchanged for the area comprising the rest of the gorges but it has been included in this account.

This paper is based on: (i) five personal visits to the Park, in April, 1967; February and October, 1968; June, 1969; and March, 1970; thus covering all seasons of the year; (ii) lists of birds observed by members of the Nature Conservation Department Survey, October, 1954; by Messrs. J. H. and P. H. Hofmeyr in September, 1961; and Mr. Philip Tongue in July, 1968; and filed in the Percy FitzPatrick Institute of African Ornithology.

No long-term data on the climate are available for the Park, but it is * Percy FitzPatrick Institute of African Ornithology, University of Cape Town. 
unlikely to differ materially from that of Kakamas, 25 miles to the east. Here the average annual rainfall is $130.5 \mathrm{~mm}$, mostly falling between January and April and $68 \%$ between October and March. However, as in all arid areas, the rainfall is very variable from year to year; and this affects both the numbers and the breeding seasons of the birds. The mean maximum daily temperature varies from $35.7^{\circ} \mathrm{C}$ in January to $20.9^{\circ} \mathrm{C}$ in July and the mean daily minima from $19^{\circ} \mathrm{C}$ in January to $4.1^{\circ} \mathrm{C}$ in July. The extremes are $43.3^{\circ} \mathrm{C}$ in January and $-4.7^{\circ} \mathrm{C}$ in July.

According to Köppen's classification, the climate of Augrabies falls into his BWkw', which is a desert climate; and according to Thornthwaite's classification it is EB'd, or Arid Warm (Schulze, 1947).

I have kept daily lists of all species observed on all five visits. These number 37 , and the following species occur in 28 or more and are therefore the most likely to be seen by a visitor:

Cape Turtle Dove, Laughing Dove, Cape Coly, Pied Barbet, Rock Martin, African Sand Martin, Red-eyed Bulbul, Pririt Batis, Blackchested Prinia, Familiar Chat, Cape Robin, Karoo Robin, Cape Wagtail, Pale-winged Starling, Dusky Sunbird, Pale White-eye, Cape Sparrow, Masked Weaver, Red Bishop, Yellow-rumped Canary and Whitethroated Seed-eater.

The following species, though not recorded so frequently, were seen on every visit and should be seen if looked for:

Fish Eagle, Chanting Goshawk, Cape Francolin, Three-banded Plover, Namaqua Sandgrouse, Rock Pigeon, Namaqua Dove, Swallowtailed Bee-eater, Red-faced Coly, Sabota Lark, Spike-heeled Lark, Grey Tit, Tit-babbler, Chat Flycatcher, Crombec, Yellow-bellied Eremomela, Rufous-eared Warbler, Namaqua Prinia, Olive Thrush, Mountain Chat, Fiscal, Brubru, Bokmakierie, Red-shouldered Starling, Greyheaded Sparrow, Scaly Weaver, Red-billed Quelea, Red-billed Firefinch, Common Waxbill, Yellow Canary, Cape Bunting and Lark-like Bunting.

In the Systematic List which follows, an asterisk indicates that one or more specimens have been collected, by me or by others. Nomenclature follows the South African Ornithological Society "Check List" (1969).

\section{Systematic List}

Reed Cormorant, Phalacrocorax africanus, Rietduiker

One on the river, 16 April, 1967.

Grey Heron, Ardea cinerea, Blou Reier

Singles seen not infrequently on the river or flying over.

Black-headed Heron, A. melanocephala, Swartkop Reier

Seen frequently, chiefly in lucerne; singles.

Hamerkop, Scopus umbretta, Hamerkop

Always present along the river, especially at drying pools.

White Stork, Ciconia ciconia, Groot Wit Sprinkaanvoël

One flying over, 4 February, 1968.

Black Stork, C. nigra, Groot Swart Sprinkaanvoël 
Seen in February, June and October, so evidently resident. May breed in the gorge.

White-bellied Stork, C. abdimii, Klein Swart Sprinkaanvoël

Two in lucerne on edge of the Park, 22 February, 1968.

African Shelduck, Tadorna cana, Bergeend

Noted flying over twice in April, 1967.

Egyptian Goose, Alopochen aegyptiacus, Kolgans

Always about, in pairs or small parties.

Black Duck, Anas sparsa, Swart Eend

Scarce, but a resident species, usually seen in pairs.

Cape Wigeon, A. capensis, Teeleendjie

Two on the river, 23 and 24 April, 1967; and 7 and 13 June, 1969.

Yellow-billed Kite, Milvus migrans, Geelbek-wou

Noted on two days in February, 1968; more regular near the hotel, three miles east.

Black-shouldered Kite, Elanus caeruleus, Blouvalkie

Noted 20 and 25 October, 1968, and 7 June 1969.

Black Eagle, Aquila verreauxi, Witkruis-arend

Nesting in the gorges below the Falls, 12 June, 1969.

Martial Eagle, Polemaetus bellicosus, Breëkop-arend

Seen on three days in October, 1968, an immature.

Black-breasted Snake-Eagle, Circaetus gallicus, Swartbors-slangarend

Seen on four days in April, 1967, two together on the 15th, otherwise singly.

African Fish-eagle, Haliaeetus vocifer, Visarend

Regular on the river.

Steppe Buzzard, Buteo buteo, Bruin Jakkalsvoël

Noted 25 February, 1968, and 12 March, 1970.

Jackal Buzzard, B. rufofuscus, Jakkalsvoël

Rare; seen on three days on three different visits in Namaqua

Broken Veld.

Chanting Goshawk, Melierax musicus, Groot Witvalk

One or two present in Namaqua Broken Veld on all visits.

Lanner, Falco biarmicus, Edelvalk

One in Namaqua Broken Veld, 13 April, 1967; and an immature at the Red Bishop colony, 21-24 February, 1968.

Rock Kestrel, $F$. tinnunculus, Rooivalkie

Namaqua Broken Veld; but thinly distributed.

Greater Kestrel, F. rupicoloides, Groot Rooivalkie

One in Namaqua Broken Veld, 16 April, 1967.

Pygmy Falcon, Poliohierax semitorquatus, Dwergvalkie

A pair near a nest of Philetairus socius, 8 June, 1969. Previously recorded by P. Tongue, July, 1968.

Cape Francolin, Francolinus capensis, Kaapse Fisant

Riverine bush; has undoubtedly increased over the last three years. 
Quail, Coturnix coturnix, Afrikaanse Kwartel

Noted on two days in October, 1968.

Helmeted Guineafowl, Numida meleagris, Tarentaal

Only on two days in October, 1968.

Ludwig's Bustard, Otis ludwigii, Ludwigse Pou

Seen singly or in a pair on three days in April, 1967; two, 22

October, 1968. In Namaqua Broken Veld.

Water Dikkop, Burhinus vermiculatus, Waterdikkop

Noted, 23 October, 1968 and 11-14 March, 1970; also recorded

by the N.C.D. party, October, 1954.

Blacksmith Plover, Vanellus armatus, Bontkiewietjie

Resident on pools near the river.

Three-banded Plover, Charadrius tricollaris, Drieband-strandlopertjie

Common on pools and beside the river.

Common Sandpiper, Tringa hypoleucos, Gewone Ruiter

One on a pool in the river, 10 March, 1970.

Wood Sandpiper, T. glareola, Bosruiter

Seen on pools near the river, 23 and 25 February, 1968.

Namaqua Sandgrouse, Pterocles namaqua, Kelkiewyn

Always present but in widely fluctuating numbers.

Breeding, October, 1968. Mr. Bruwer reports a big eastward migration in April, 1969.

Double-banded Sandgrouse, $P$. bicinctus, Dubbelband-sandpatrys

A male and two females in the rocky hills below the Falls, 12 April, 1967. In March, 1970, at least 30 were noted coming to drink at dusk at pools in the river on the north bank.

Rock Pigeon, Columba guinea, Bosduif

Common in and near the gorges, whence it forages far into the surrounding country.

Cape Turtle Dove, Streptopelia capicola, Tortelduif

Abundant in riverine bush and Namaqua Broken Veld. Breeding in June, 1969.

Laughing Dove, S. senegalensis, Rooibors-duifie

Fairly common in riverine bush. Breeding in June, 1969.

Namaqua Dove, Oena capensis, Namakwa-duifie

Always present in riverine bush and Namaqua Broken Veld but in varying numbers. Breeding in June, 1969.

Didric Cuckoo, Chrysococcyx caprius, Diedrikkie

A young bird being fed by Cape Sparrows in riverine bush, 12-17 April, 1967; and heard calling, 24 October, 1968; and 11 June, 1969.

Rosy-faced Lovebird, Agapornis roseicollis, Rooikop-parakiet

Although sometimes present in big flocks, my only personal encounters with it are of one or two in riverine bush, 21-24

February, 1968; and, up to 8, 8-11 March, 1970.

Giant Eagle-owl, Bubo lacteus, Reuse-ooruil 
Recorded by P. Tongue, July, 1968.

Spotted Eagle Owl, B. africanus, Gevlekte Ooruil

One by the river, 10 March, 1970.

Barn Owl, Tyto alba, Nonnetjie-uil

Heard in the camp on four nights in October, 1968.

Rufous-cheeked Nightjar, Caprimulgus rufigena, Rooiwang-naguil

Noted twice in October, 1968, and once in March, 1970.

Pied Kingfisher, Ceryle rudis, Bont Visvanger

One, 11 June, 1969. Also noted by Tongue, July, 1968.

Malachite Kingfisher, Alcedo cristata, Kuifkop-visvanger

Two at a pool, 25 February, 1968. Also noted by J. H. and P. K.

Hofmeyr, September, 1961.

European Bee-eater, Merops apiaster, Europese Byvreter

Not observed by me but recorded by the N.C.D. party in October, 1964.

Swallow-tailed Bee-eater, M. hirundineus, Mikstert-byvreter

Regular and common in riverine bush.

Hoopoe, Upupa epops, Hoephoep

Resident in riverine bush.

Scimitarbill, Rhinopomastus cyanomelas, Swartbek-kakelaar

Resident in riverine bush but not common.

Cape Coly, Colius colius, Witkruis-muisvoël

Numerous in riverine bush. Breeding, February, 1968.

Red-faced Coly, C. indicus, Rooiwang-muisvoël

Sporadic in riverine bush.

Black Swift, Apus barbatus, Swart Windswawel

I have not seen it but it is recorded by others.

Alpine Swift, A. melba, Grootste Windswawel

Common in the gorges, whence it ranges far over the veld; but inexplicably absent, March, 1970. Augrabies birds belong to the

South West African race, A. m. marjoriae.

White-rumped Swift, A. caffer, Witkruis-windswawel

Only 25th February, 1968.

Little Swift, $A$. affinis, Klein Windswawel

Noted twice in October, 1968.

*Pied Barbet, Lybius leucomelas, Bont Houtkapper

Common in riverine bush and Namaqua Broken Veld.

*Golden-tailed Woodpecker, Campethera abingoni, Goudstert-spegt

Regular in riverine bush.

*Cardinal Woodpecker, Dendropicos fuscescens, Kardinaal-spegt

Regular in riverine bush.

Greater Honeyguide, Indicator indicator, Groot Heuningwyser

Heard in riverine bush, 11 April, 1967.

*Lesser Honeyguide, I. minor, Klein Heuningwyser

Noted twice in riverine bush in October, 1968, and once in June, 1969. 
*Sabota Lark, Mirafra sabota, Sabota-lewerkie

Resident, and at times common, in Namaqua Broken Veld. In

breeding condition, April, 1967.

Grey-backed Finch-Lark, Eremopterix leucotis, Grys Kaffertjie

Present always, but in fluctuating number, in Namaqua Broken

Veld. Many in April, 1967 and October, 1968.

Black-eared Finch-Lark, E. australis, Egte Kaffertjie

Recorded by the Nature Conservation Department Survey,

October, 1964.

*Long-billed Lark, Certhilauda curvirostris, Langbek-lewerkie

Common in Namaqua Broken Veld.

Karoo Lark, C. albescens, Karoo-lewerkie

Only in April, 1967, when common for several days in Namaqua

Broken Veld.

Spike-heeled Lark, C. albofasciata, Vlakvoëltjie

Common in Namaqua Broken Veld. Nest with well-grown young,

15 April, 1967.

European Swallow, Hirundo rustica, Europese Swawel

Common in riverine bush and Namaqua Broken Veld in February, 1968.

White-throated Swallow, H. albigularis, Witkeel-swawel

A few near the river, February, March, April and October.

Pearl-breasted Swallow, H. dimidiata, Pêrelbors-swaweltjie

One record, 20 October, 1968.

*Rock Martin, H. rupestris, Kransswawel

Abundant in the gorges and forages over the Namaqua Broken

Veld.

African Sand Martin, Riparia paludicola, Afrikaanse Oewerswawel

Abundant near the river.

Fork-tailed Drongo, Dicrurus adsimilis, Mikstert-byvanger

I have not identified it but it is recorded by J. H. and P. K.

Hofmeyr, September, 1961.

Grey Tit, Parus afer, Pietjoujou

Regular, but not numerous, in riverine bush.

*Red-eyed Bulbul, Pycnonotus nigricans, Rooioog-tiptol

Numerous in riverine bush and Namaqua Broken Veld. Feeding

fledged young, April 1967.

Spotted Flycatcher, Muscicapa striata, Europese Vlieëvanger

Noted on two days in February, 1968, in riverine bush; quite common there in March, 1970.

Tit-babbler, Parisoma subcaeruleum, Tjeriktik

Riverine bush; not very common.

*Chat Flycatcher, Melaenornis infuscata, Groot Vlieëvanger

Fairly common in Namaqua Broken Veld. Nest with young and a fledged juvenile, April, 1967.

Pririt Batis, Batis pririt, Pririt-bosbontrokkie 
Common in riverine bush and Namaqua Broken Veld.

Fairy Flycatcher, Stenostira scita, Feë-vlieëvanger

Two in riverine bush, 11 June, 1969; one, 11 and 12 March, 1970.

*African Marsh Warbler, Acrocephalus baeticatus, Klein Rietsanger

Regular in the reed-beds on the edge of the Park; and occasional in riverine bush.

Cinnamon-breasted Warbler, Camaroptera subcinnamomea, Kaneelborssanger

I have not identified it but it is said to occur and there is suitable habitat.

Yellow-bellied Eremomela, Eremomela icteropygialis, Geelbuik-Bossanger

Fairly common in Namaqua Broken Veld.

Long-billed Crombec, Sylvietta rufescens, Krombek

Riverine bush and Namaqua Broken Veld; uncommon.

Fan-tailed Cisticola, Cisticola juncidis, Gewone Veldtingtinkie

Noted in lucerne, February and October, 1968, and June, 1969, and March, 1970.

*Grey-backed Cisticola, C. subruficapilla, Grysrug-tingtinkie

Namaqua Broken Veld; uncommon.

*Rufous-eared Warbler, Prinia pectoralis, Rooioor-kleinjantjie

Fairly common in Namaqua Broken Veld.

*Black-chested Prinia, P. flavicans, Swartbors-Langstert-tingtinkie

Riverine bush and Namaqua Broken Veld; but not very common.

Namaqua Prinia, P. substriata, Namakwa-langstert-tingtinkie

Common in riverine bush.

*Olive Thrush, Turdus olivaceus, Kaapse Lyster

Common in riverine bush and has increased during the last three years.

Mountain Chat, Oenanthe monticola, Bergtapuit

Regular in Namaqua Broken Veld and round the camp, where it has bred.

Capped Wheatear, O. pileata, Skaapwagter

One in Namaqua Broken Veld, 11 April, 1967.

*Familiar Chat, Cercomela familiaris, Spekvreter

Fairly common in riverine bush.

Tractrac Chat, C. tractrac, Klein Spekvreter

Common in Namaqua Broken Veld.

Karoo Chat, C. schlegelii, Bleektapuit

Fairly common in Namaqua Broken Veld.

Ant-eating Chat, Myrmecocichla formicivora, Swartpiek

Seen in Namaqua Broken Veld on two days in October, 1968.

Cape Robin, Cossypha caffra, Janfrederik

Common in riverine bush.

Kalahari Robin, Erythropygia paena, Wipstert

Occasional in Namaqua Broken Veld.

*Karoo Robin, E. coryphaeus, Slangverklikker 
Common in riverine bush and Namaqua Broken Veld.

African Pied Wagtail, Motacilla aguimp, Bont Kwikkie

Sparingly distributed along the river.

Cape Wagtail, M. capensis, Kwikkie

Common on the river and in the camp.

*Richard's Pipit, A. novaeseelandiae, Gewone Koester

Seen on two days in October, 1968.

Long-billed Pipit, A. similis, Nicholsonse Koester

I have not seen it, but it is recorded by others.

Fiscal, Lanius collaris, Laksman

Sparse; riverine bush and Namaqua Broken Veld.

Red-backed Shrike, L. collurio, Rooirug-laksman

Two, 10 March, 1970.

Brubru, Nilaus afer, Bontrok-laksman

Riverine bush; but uncommon.

Bokmakierie, Malaconotus zeylonus, Bokmakierie

Fairly common, chiefly in Namaqua Broken Veld but sometimes very tame in the camp.

Red-shouldered Starling, Lamprotornis nitens, Klein Glansspreeu

Sparse; Namaqua Broken Veld.

*Pale-winged Starling, Onychognathus nabouroup, Bleekvlerk-spreeu

Abundant in the Gorges, Namaqua Broken Veld, and riverine

bush. Feeding fledged young, April, 1967 and March, 1970.

Dusky Sunbird, Nectarinia fusca, Namakwa-suikerbekkie

Abundant in riverine bush and Namaqua Broken Veld. Breeding in June.

Lesser Double-collared Sunbird, $\mathcal{N}$. chalybea, Klein Rooibors-suikerbekkie

A single male in riverine bush, 25 February, 1968.

*Pale White-eye, Zosterops pallidus, Kaapse Glasogie

Abundant in riverine bush.

House Sparrow, Passer domesticus, Engelse Mossie

Does not seem to have established itself in the camp but occurs occasionally.

Great Sparrow, P. motitensis, Groot Mossie

Sparse, riverine bush. Nest-building, February, 1968.

*Cape Sparrow, P. melanurus, Mossie

Common in riverine bush. Feeding young in the nest, fledged young and a young Didric Cuckoo, April, 1967; nest-building and feeding fledged young, June, 1969; young in the nest, March, 1970.

Grey-headed Sparrow, P. griseus, Gryskop-mossie

Sparse; riverine bush.

White-browed Sparrow-Weaver, Plocepasser mahali, Koringvoël

Singles seen on two days in March, 1970.

*Social Weaver, Philetairus socius, Familievoël

At least one nesting colony in Namaqua Broken Veld, where for- 
aging parties are encountered from time to time.

*Scaly Weaver, Sporopipes squamifrons, Baardmannetjie

Was common and breeding in Namaqua Broken Veld, April, 1967; sparse on other visits.

Masked Weaver, Ploceus velatus, Swartkeel-geelvink

Abundant in riverine bush.

Red-billed Quelea, Quelea quelea, Rooibek-vink

There were few in February, 1968; on other visits, present in

flocks in riverine bush and Namaqua Broken Veld.

Red Bishop, Euplectes orix, Rooi Kaffervink

Abundant in the reed-bed on the edge of the Park.

Red-billed Firefinch, Lagonosticta senegala, Rooibek-robbin

Common in riverine bush; appears to have increased in the last three years.

Common Waxbill, Estrilda astrild, Rooibekkie

In riverine bush, often abundantly.

Pin-tailed Whydah, Vidua macroura, Koning-rooibekkie

Regular in riverine bush.

Yellow-rumped Canary, Serinus atrogularis, Bergkanarie

Common, Namaqua Broken Veld and riverine bush. Breeding, April, 1967.

Black-headed Canary, S. alario, Swartkop-kanarie

Recorded once, at a pool, 25 February, 1968. It was an example of the northern race, $S$. a. leucolaema.

Yellow Canary, S. faviventris, Geelsysie

Namaqua Broken Veld; not numerous.

*White-throated Seed-eater, S. albogularis, Witkeel-dikbek-sysie

Common in Namaqua Broken Veld, and riverine bush.

*Cape Bunting, Emberiza capensis, Streepkoppie

Common where there are rocks.

*Lark-like Bunting, E. impetuani, Vaal Streepkoppie

Abundant, Namaqua Broken Veld. Breeding, April, 1967, and June, 1969.

The following sight-records have been omitted from this list pending confirmation:

Rufous-necked Kestrel, Falco chicquera, Rooinek-valkie

Little Bee-eater, Merops pusillus, Klein Byvreter

Pennant-winged Nightjar, Macrodipteryx vexillarius, Wimpelvlerk-naguil

Marico Flycatcher, Melaenornis mariquensis, Marico-vlieëvanger

Red-winged Starling, Onychognathus morio, Rooivlerk-spreeu

Pied Starling, Spreo bicolor, Witgat-spreeu

Black Widow-Finch, Hypochera funerea, Blou Vinkie. (If Hypochera sp. does occur, it would almost certainly be $H$. amauropterix, which parasitises

Lagonosticta senegala).

The following species, recorded from the vicinity of the Falls Hotel, will undoubtedly be found within the Park limits in due course: 
Red-knobbed Coot, Fulica cristata, Bleshoender

Greenshank, Tringa nebularia, Groenpoot-ruiter

In addition, Mirafra africanoides, the Fawn-coloured Lark, Vaalbruinlewerkie, is known from the area north of the river between the Park boundary and Kakamas and may be expected to occur in the Park too.

\section{Acknowledgements}

I am much indebted to the National Parks Board of Trustees and their staff for permission to work in the Park and for many facilities granted me. In particular, I am most grateful to the Ranger at Augrabies, Mr. W. Bruwer, and his wife for all their kindness and hospitality.

I must also acknowledge the help of my wife, who skinned the specimens, managed the camp and helped with the identifications and with the driving on the long road between Cape Town and the Park.

\section{REFERENCES}

ACOCKS, J. H. P. 1953. Veld Types of South Africa. Mem. Bot. Surv. S. Afr. 28. SCHULZE, P. R. 1947. The Climates of South Africa according to the Classifications of Köppen and Thornthwaite. S. Afr. Geogr. F. 29.

SOUTH AFRICAN ORNITHOLOGICAL SOCIETY. 1969. Check List of the Birds of South Africa. Cape Town. 